\section{RECONSTRUCTION IN WALES}

T HE first interim report of the Welsh Reconstruction Advisory Council, appointed on June 30,1942 , "to survey, in conformity with the general examination of reconstruction problems now being conducted by the Government, those problems of reconstruction which are of special application to Wales and Monmouthshire, and to advise on them", which has now been issued by the Minister of Reconstruction*, emphasizes that its inquiry is in the nature more of a continuous survey than of an exhaustive examination of specific subjects. The report records the Council's considered opinion as to the state of affairs likely to emerge in Wales after the conclusion of the present War, together with an outline of the kind of measures which will be required in any comprehensive plan for the economic and social rehabilitation and development of the region. It includes a survey of the field already covered by the Council during its first year's work and an indication of the nature of the work which remains to be done.

The first part of the report includes a historical retrospect which emphasizes that the Welsh people claim that experience of the past shows that plans must be made in advance as an essential part of the war effort. The Committee is also insistent that this matter of preparation for the future should not be dissociated from the life of the people affected by entrusting the whole task to any remote central body of experts. In broad outline, at least, such planning must be the function, if not of the people themselves, at any rate of those who know the needs of the people and of the areas.

This part of the report, which clearly owes something to the "Second Industrial Survey of South Wales", makes five major assumptions which underlie all the Council's discussions and recommendations : (a) that the War will result in a victory for the United Nations ; $(b)$ that the War against Germany will end first and hostilities will consequently taper off rather than cease abruptly; (c) that sooner or later there will be in Great Britain as a whole, and in Wales in particular, a considerable body of labour to be reabsorbed into peace-time occupations, and an economic situation of sufficient difficulty to demand exceptional measures, planned in advance; $(d)$ that the Government's policy will be directed primarily to the maintenance of a high level of employment; and (e) that for a considerable period after the end of the War sufficient control will be maintained over the disposition of essential raw materials, plant and equipment, labour supplies (including demobilization) and the utilization and construction of factory premises to avoid the worst excesses of a "first come, first served' scramble.

The post-war demand for labour in Wales will be determined by the future course of international trade and by the nature and extent of the home market demand. Certain further assumptions are made with regard to both these factors, and the report then emphasizes that there are other fundamental questions of national policy which will condition any regional plan and concerning which any assumptions are unwise in the absence of decisions by the Government. For example, in regard to planning, the interests of Wales will not be served.

* Office of the Minister of Reconstruction. Welsh Reconstruction Advisory Council. First Interim Report. Pp. 132. (London : H.M. Stationery Office, 1944.) 28. net. unless the central planning authority to be established accepts and acts upon the principle of decentralization and devolves very large powers upon regional bodies, the activities of which will be coordinated by the central authority. Any new Welsh regional economic planning authority must be organized along lines that are at once flexible and powerful.

Reviewing the five phases through which post-war reconstruction in Great Britain as a whole may be expected to pass-momentary dislocation, first reconstruction boom, general prosperity, turn of the tide, and second reconstruction effort-the Council points out that the greatest danger of the first boom period is that it will encourage in Wales an attitude of complacency, leading to the deferment of thought about the need for fundamental changes in the basic industries (or even the denial of the need for them) together with a failure to take urgent steps to broaden the industrial basis. It also emphasizes the strictly temporary nature of war-time prosperity in Wales: between forty and fifty per cent of all the workers employed by new industries in a large sample area covering nearly half the population of Wales were shown in two recent surveys to be attached to establishments which must almost inevitably either close down or drastically curtail their activities at the end of the War.

Furthermore, there are four potential danger spots which are discussed in some detail. The first of these is the possibility that technological unemployment consequent upon the introduction of strip-mill methods of production in the tin-plate industry at Ebbw Vale, and the necessity to adopt such methods in the west central and western anthracite areas will lead to the emergence of a new set of depressed areas. This is an industry in which there is every reason to anticipate drastic reorganization, rationalization and considerable technological unemployment. It would be fatal to oppose a technical development which has become a necessity if the competitive power of the Welsh industry in world markets is to be maintained, but the Council recommends that careful regard should be had to any means whereby the old works can be used as subsidiary to the new strip mills. The necessary reorganization and concentration will also require agreement between the interests concermed, and this may present difficulties unless undertaken as part of the post-war reconstruction plans.

The second danger is that insufficient thought may be given to the need to make provision in the mining industry for the situation likely to be caused by the post-war closure of uneconomic pits and the early exhaustion of others. For this reason the Council recommends as a matter of urgency that all necessary steps be taken to ensure the availability of a survey of coal resources with the view of deciding the most suitable locations for development. The third danger lies in the existence in a number of areas of former mining and metallurgical townships which have completely lost their basic industry and now serve only as dormitories for workers travelling long distances to strictly temporary war factories. The fourth is the probability of a considerable volume of unemployability in certain areas. A full examination of this problem must be an essential part of any social security scheme which the Government may introduce.

The second part of the report discusses the work of the Council from June 30, 1942 to December 17, 1943. In its survey of industry the report, after 
stressing the necessity of securing an early expansion of the export trade in Welsh coal and recommending early steps to remove inequalities such as royalties and wayleave rents, urges that the Government should support mechanical firing as an alternative to oil for tramp and liner tonnage, and that the Board of Admiralty should consider its adoption, where practicable, in naval tonnage. Wales, however, may need an integrated coal-oil-power-and-chemical industry, developed as a whole, the keys to which lie in an abundant supply of cheap electricity and an extensive programme of research. Reviewing production of oil from coal, the Council recommends an early re-examination of the Fischer-Tropsch process in the light of changed circumstances, and the establishment of a trial plant in Wales after the War. It also seems desirable that further experience of lowtemperature carbonization should be gained in Wales by allowing the plant already erected there to come into operation at the earliest possible moment after the War, while it is for consideration whether the whole question of the production of oil from coal is not one which cannot be dealt with satisfactorily within the structure of private enterprise.

In regard to the slate industry, the Council recommends immediate consideration of its place in relation to the post-war building programme, while attention is also directed to the particularly useful part which the refugee firms set up in Wales could play in the rehabilitation of the devastated countries of Europe. An adequate expansion of the tourist and holiday industry in Wales is conditional upon an improvement in communications to break down its relative inaccessibility, and the highest importance is attached to the provision of a trunk road from north to south Wales, passing through the beautiful but isolated centre of Wales, and to the early provision of a road crossing over the River Severn. The provision of better road communications across the Severn below Gloucester should be announced as part of the Government's reconstruction programme, the various schemes which have been put forward to be reviewed immediately by technical experts, and all road improvements on each side of the Severn should be related to the new means of communication. Establishment of at least one trans-Atlantic aerial terminus in Wales, suitably linked with the major road and railway routes, is also recommended.

The development of the tourist industry is recognized as demanding more.study, research and planning than the Council has yet been able to give to it, and after endorsing the recommendations of the Scott Committee on this matter, the Council urges that at least one area in North Wales and one in South Wales should be developed as national parks at the earliest suitable moment after the War, with assistance from public funds if necessary.

The Council further emphasizes that Wales needs to explore very fully the potentialities of a marriage between industry and agriculture. Agriculture, the producers' goods industries, the consumers' goods industries and the tourist industry are all interdependent, and the expansion of each in Wales could, properly organized and co-ordinated, benefit all. General measures are also required to increase the industrial attractiveness of Wales-the provision of buildings of standard design, in advance of demand, on selected suitable sites, widely distributed, and the clearing and levelling of every site which, in the opinion of the regional planning authority, it is desirable to use for industrial purposes, are two sug- gested measures-while the provision of electric power at an exceptionally low cost is a fundamental requirement for many industries. Here the Council inclines to the establishment of a special Welsh electrical development board. Refitting of dairy farms is one of the most urgent of Welsh post-war agricultural problems, while in many areas there is room for substantial improvement in the general level of cleanliness and hygiene in milk distribution. In regard to grassland and ley farming, a comprehensive examination of the whole position in the light of long-term requirements, and in terms of the quantities of equipment and fertilizers that would be required, as well as of the problems of finance and land ownership that would be raised is desirable. The importance of a long-term policy of afforestation is also stressed, as well as the suitability of Wales for timber-growing; special study of the types of trees best suited for planting in different parts of Wales is recommended. Stress is also laid on the improvement of facilities for technical education, in which cooperation between industrialists and educational authorities and between the local authorities themselves is essential. In this respect the Council, commenting on the White Paper on Education, regards it as unfortunate that rearrangements should be made within the present structure for one service without reference to the general problem of the reorganization of local government as a whole.

\section{THE FATIGUE OF GLASS UNDER STRESS \\ BY E. OROWAN \\ Cavendish Laboratory, Cambridge}

$\mathrm{G}^{\mathrm{s}}$ LASS under stress shows a characteristic fatigue phenomenon of practical importance : it can be broken by stresses far below its ordinary breaking stress as measured in short-time tests, provided that the load is applied for a sufficiently long time. About one third of the short-time breaking stress is sufficient to produce fracture if it is sustained for a number of weeks. In contrast to metals, the stress need not fluctuate periodically in order to develop this fatigue phenomenon, of which the most spectacular everyday manifestation is the sudden spontaneous cracking of glasses or bottles under internal stresses which they may have withstood for many years.

As with metals, the practically important question is whether a 'safe stress' exists; that is to say, whether there is a stress limit below which the glass can stand up to the load indefinitely. Extensive experimental work has been carried out on the dependence of the time of breaking upon the breaking stress, and the latest investigations ${ }^{1,2}$ seem to lead to a relationship between these quantities that can be represented approximately by a straight line if both stress and time are plotted logarithmically. If extrapolation to longer times is justified, this would mean that no safe stress exists, and, therefore, glass would be an essentially unreliable material for use under sustained loads.

In a recent issue of Nature ${ }^{3}$, J. B. Murgatroyd has discussed this phenomenon. In his view, the influence of the duration of loading is "not easily explicable by Griffith's theory alone", and he suggests an explanation based on the assumption that glass consists of "an elastic matrix which contains small pockets of 